\title{
The effect of Ringer's acetate versus Ringer's lactate on aminotransferase changes in dengue hemorrhagic fever
}

\author{
Mulya Rahma Karyanti, MD; Hindra Irawan Satari, MD; \\ Damayanti Rusli Sjarif, MD, PhD
}

\begin{abstract}
Background Dengue hemorrhagic fever (DHF) infection causes hepatocelullar impairment. In management of DHF, World Health Organization (WHO) recommends the crystalloids Ringer's acetate $(\mathrm{RA})$ or Ringer's lactate (RL), which are similar in composition to plasma. Acetate in RA is not metabolized in the liver, hence not burdening the liver, whereas lactate in RL is metabolized mostly in the liver, thus placing a burden on the liver.

Objective To compare aminotransferase changes as markers of hepatocellular impairment subsequent to the use of $R A$ and $R L$ in the management of DHF with and without shock.

Methods This study was a double-blind randomized controlled trial on DHF patients aged 1-18 years in Cipto Mangunkusumo Hospital who had not received prior treatment with crystalloids or colloids. Subjects were randomly assigned to receive either RA or $\mathrm{RL}$ intravenously. Aminotransferase levels were examined on the first, second and third weeks from the onset of fever.

Results Ninety-two patients who fulfilled inclusion criteria were enrolled in this study, consisting of those without and with shock. Mean transaminase levels of patients without shock in the RA and $\mathrm{RL}$ groups did not differ significantly. Mean transaminase levels of patients with shock in the RA group were lower than those in the $\mathrm{RL}$ group, but this difference was not significant statistically. Mean alteration of transaminase levels in patients with and without shock were not significantly different.

Conclusion In DHF without shock, there is no significant difference between aminotransferase level changes of patients receiving RA and RL solutions. In DHF with shock, aminotransferase levels of patients receiving $R A$ tend to be lower than those receiving $R L$, but this difference is insignificant [Paediatr Indones 2005;45:81-86].
\end{abstract}

Keywords: hepatocellular impairment, dengue haemorrhagic fever, Ringer's acetate, Ringer's lactate, aminotransferase
$\mathrm{D}$ engue hemorrhagic fever (DHF), is an acute, self-limited illness characterized by fever, bleeding, and sometimes shock. ${ }^{1-3}$ In a patient with DHF, capillary permeability increases; even more so in dengue shock syndrome (DSS). The capillary permeability of a healthy child is higher than that of a healthy adult, rendering children more vulnerable to shock. ${ }^{4}$

The liver is one of the target organs of dengue infection and the clinical manifestations of hepatocelullar impairment are shown by increased aminotransferase levels. In the dengue-infected liver, pathological findings show centrilobular necrosis, fatty changes, Kuppfer cell hyperplasia, and acidophilic and monocytic infiltration from the portal tract. Aminotransferase levels usually increase, reaching maximum levels 9 days after the onset of fever, and decrease gradually to normal levels by the 14 th day. ${ }^{5}$

The principle of DHF management is supportive treatment by replacing the volume of plasma lost through increased capillary permeability and bleeding. ${ }^{6}$ Massive bleeding may occur if hemostatic impairment such as vasculopathy, thrombocytope-

From the Department of Child Health, Medical School, University of Indonesia, Jakarta, Indonesia.

Reprint requests to: Mulya Rahma Karyanti, MD, Department of Child Health, University of Indonesia, Cipto Mangunkusumo Hospital, Jakarta, Indonesia. Tel. 62-21-3147342; Fax. 62-21-3148931; Email: karyanti@telkom.net. 
nia and coagulopathy persist. 7,8 Specific fluid therapy is needed for children with DHF because the water composition and requirement in children differ from adults. ${ }^{9}, 10 \mathrm{WHO}$ has recommended crystalloid solutions such as Ringer's lactate (RL), Ringer's acetate (RA), and normal saline for the management of DHF. RA and RL are similar in composition to the intravascular plasma. ${ }^{11,12} \mathrm{RA}$ has a potential advantage over RL, since acetate can be metabolized in almost all muscles and does not burden the liver, while most lactate must be metabolized by the liver. RA, as an alternative to RL, should be considered in DHF patients with severe liver impairment, in whom the liver's ability to eliminate lactate is decreased. ${ }^{13}$ Until the present time, $\mathrm{RL}$ is widely used in the Department of Child Health, Cipto Mangunkusumo Hospital, while no study comparing the use of RA and RL in DHF patients has been done. This study aims to compare aminotransferase changes subsequent to the use of RA and RL in the management of DHF patients with and without shock.

\section{Methods}

This study was a double-blind randomized controlled trial conducted on DHF patients in the Department of Child Health, Cipto Mangunkusumo Hospital, during a dengue epidemic from May 2003 until March 2004. The diagnostic criteria of DHF were based on WHO's Technical Guide for Diagnosis, Treatment, Prevention and $\mathrm{C}$ ontrol of DHF.? Severity of the disease was graded according to the 1997 WHO criteria, ${ }^{7}$ in which grade I DHF was defined as fever accompanied by non-specific constitutional symptoms, with a positive tourniquet test as the only hemorrhagic manifestation; grade II as spontaneous bleeding in addition to grade I manifestations; grade III as circulatory failure manifested by rapid and weak pulse, narrowing of pulse pressure or hypertension, with the presence of cold, clammy skin and restlessness; and grade IV as profound shock with undetectable blood pressure.

Subjects consisted of patients aged 1-18 years who were diagnosed with DHF based on the above criteria and had not received prior treatment with crystalloid or colloid solutions, whose parents gave informed consent. Patients were excluded from this study when they had a history of liver disease and/or a family history of chronic liver disease, myocarditis, or rhabdomyolysis, had recurrent or prolonged shock, did not have completed transaminase examinations, or died. The study was approved by the Committee of Medical Research Ethics, Medical School, University of Indonesia.

Sample size for this study was determined by using 95\% confidence interval and power of $80 \%$. Statistical significance was set at $\mathrm{P}<0.05$. Based on this calculation, 92 subjects were required, consisting of 46 subjects with shock (DHF/DSS grade III and IV) and 46 without (DHF grade II). Subjects were randomly allocated to receive infusions of either RA or RL such, that there were an equal number of subjects in the RA with shock, RL with shock, RA without shock, and RL without shock groups, respectively. Fluid management was given according to the $1997 \mathrm{WHO}$ standard procedure.

Subjects were examined for complete blood count and aminotransferase levels. Complete blood count was performed every 6 hours for 48 hours since the patient's admission. Aminotransferase levels, comprising aspartate transaminase (AST) and alanine transaminase (ALT) levels were examined from blood samples taken on the first week (S1), second week (S2), and third week (S3) from the onset of fever. The level considered normal was $<40 \mathrm{U} / \mathrm{l}$ for AST and $<40 \mathrm{U} / 1$ ALT. The increase in aminotransferase levels was considered mild if $\leq 100 \mathrm{U} / 1$, moderate if 101-200 U/1, and severe if $>201 \mathrm{U} /$.

The collected data were processed using SPSS 10.5 for Windows. Statistical analyses were performed using the chi-square test, the Kolmogorov-Smirnov test, and the Mann-Whitney test, where appropriate.

\section{Results}

Between May 2003 and March 2004, 201 DHF patients were admitted to Cipto Mangunkusumo Hospital. One hundred and twelve cases were included in this study and followed. In the process, 20 patients dropped out (12 had incomplete data, 6 died from prolonged shock, encephalopathy, respiratory failure, and massive gastrointestinal bleeding, and 2 had extreme transaminase levels). Finally, only $92 \mathrm{DHF}$ patients who fulfilled the inclusion criteria could be further examined and analyzed. These consisted of 46 subjects with shock and 46 without. Among the subjects with shock, 23 
subjects each belonged to the RL and RA groups. A similar subject distribution occurred among subjects without shock. The final subject allocation can be seen in Figure 1. The distribution of subjects according to sex and age group are shown in Table 1 . Sex distribution was similar between patients with and without shock. Most patients were aged between 5 to 14 years. More children aged $<5$ years experienced shock compared to those of older age. With adequate fluid management, all subjects recovered completely.

Comparison between the mean AST and ALT levels of the RA and RL groups is provided in Table 2 .

In subjects without shock, the highest transaminase levels were recorded at S2 in both the RA and RL groups. Analysis of the mean AST levels of the
RA and RL groups at S1, S2, and S3 did not yield statistically significant difference. Similar analysis of the mean ALT levels of the same groups did not reveal significant difference (Table 2 ).

In subjects with shock, transaminase levels in the RA and RL groups had a comparable starting point. At S2 and S3, transaminase levels in the RA group were lower than RL group, but this difference was not statistically significant. The difference between mean transaminase levels of the RA and RL groups at S1, S2 and S3 was not statisticaly significant, either (Table 2).

This study also compared the mean alteration of transaminase levels in the RA and RL groups (Table 3).

Statistically significant difference was not found between the RA and RL groups in patients both with



Figure 1. Aminotransferase changes in DHF patients recieving Ringer's acetate Versus Ringer's lactate receiving.

Table 1. Distribution of subjects according to SeX AND Age group

\begin{tabular}{|c|c|c|c|c|c|c|c|c|}
\hline & \multicolumn{4}{|c|}{ Without shock } & \multicolumn{4}{|c|}{ With shock } \\
\hline & \multicolumn{2}{|c|}{ RA } & \multicolumn{2}{|c|}{$\mathbf{R L}$} & \multicolumn{2}{|c|}{ RA } & \multicolumn{2}{|c|}{$\mathbf{R L}$} \\
\hline & $n=23$ & $\%$ & $n=23$ & $\%$ & $n=23$ & $\%$ & $n=23$ & $\%$ \\
\hline \multicolumn{9}{|l|}{$\overline{\operatorname{Sex}}$} \\
\hline Male & 10 & (43.5) & 11 & (47.8) & 11 & (47.8) & 7 & (30.4) \\
\hline Female & 13 & (56.5) & 12 & (52.2) & 12 & (52.2) & 16 & (69.6) \\
\hline \multicolumn{9}{|l|}{ Age } \\
\hline $1-4$ years & 3 & (13.0) & 4 & (17.4) & 7 & (30.4) & 6 & (26.1) \\
\hline $5-9$ years & 7 & (30.4) & 11 & (47.8) & 9 & (39.1) & 11 & $(47.8)$ \\
\hline $10-14$ years & 12 & (52.2) & 8 & (34.8) & 7 & (30.4) & 6 & (26.1) \\
\hline $15-18$ years & 1 & $(4.3)$ & & & & & & \\
\hline
\end{tabular}


and without shock, although in subjects without shock mean transaminase alterations were highest from S2 to $\mathrm{S} 3$ in both the RA and RL groups (Table 3). In sum, it was shown that AST and ALT levels increased on the second week after fever onset both in patients with and without shock. After the second week and into the third week, transaminase levels decreased. In addition, the study indicated that AST levels tend to be higher than ALT levels in all groups.

\section{Discussion}

Liver involvement in dengue infection has been reported to be mild and manifested by the rise of liver enzyme levels. ${ }^{5}$ However, reports have been made of fulminant hepatitis with high mortality in patients with dengue infection. ${ }^{14}$ Innis et all ${ }^{17}$ reviewed the clinical course and liver histopathology of 19 fatal cases of dengue infection. In his study, acute liver failure was identified as a cause of death in DHF patients infected by dengue virus types 1,2 and 3. In Indonesia, the virus type most frequently found in DHF patients is type 3, which is associated with severe and fatal cases. ${ }^{17-20}$

Lin et al has proven in vitro that dengue virus can infect diverse liver cells with differing replication efficiency, causing cytopathic effects (CPEs) of diverse severity. Among the CPEs, the increased AST levels was correlated with the clinical results from 24 DHF patients, who showed increased AST levels at the onset of fever. ${ }^{22}$

Complete liver function test should include examinations of albumin, prothrombin time, bilirubin, transaminase, and gamma-glutamyl transpeptidase. AST and ALT are very sensitive indicators to evaluate liver impairment. ${ }^{23-28}$ This was the rationale for the use of transaminase levels to evaluate hepatocellullar impairment in this study.

In the beginning of this study, blood samples for transaminase examinations were planned to be taken

Table 2. Comparison between mean transaminase leVels of RA and RL groups

\begin{tabular}{|c|c|c|c|c|c|c|}
\hline \multirow{2}{*}{$\begin{array}{l}\text { Mean } \\
\text { transaminase } \\
\text { levels }(\mathrm{U} / \mathrm{l})\end{array}$} & \multicolumn{3}{|c|}{ Without shock } & \multicolumn{3}{|c|}{ With shock } \\
\hline & $\begin{array}{l}\text { RA } \\
(\text { mean } \pm S D)\end{array}$ & $\begin{array}{l}\mathbf{R L} \\
(\text { mean } \pm S D)\end{array}$ & $\mathbf{P}$ & $\begin{array}{l}\text { RA } \\
(\text { mean } \pm S D)\end{array}$ & $\begin{array}{l}\mathbf{R L} \\
(\text { mean } \pm S D)\end{array}$ & $\mathbf{P}$ \\
\hline \multicolumn{7}{|l|}{ AST } \\
\hline S1 & $97.91 \pm 148.36$ & $50.61 \pm 23.37$ & $0.531^{*}$ & $102.70 \pm 86.34$ & $113.70 \pm 92.91$ & $0.373^{*}$ \\
\hline S2 & $100.43 \pm 122.03$ & $68.04 \pm 59.78$ & $0.119^{*}$ & $80.35 \pm 55.35$ & $211.78 \pm 352.20$ & $0.350^{*}$ \\
\hline $\begin{array}{l}\text { S3 } \\
\text { ALT }\end{array}$ & $31.17 \pm 17.94$ & $30.61 \pm 15.11$ & $0.454^{*}$ & $38.04 \pm 26.62$ & $89.00 \pm 135.52$ & $0.198^{*}$ \\
\hline $\begin{array}{l}\text { ALI } \\
\text { S1 }\end{array}$ & $48.39 \pm 73.09$ & $23.48 \pm 12.58$ & $0.226^{*}$ & $41.26 \pm 41.63$ & $47.61+50.66$ & $0.482^{*}$ \\
\hline S2 & $60.13 \pm 96.51$ & $32.48 \pm 23.51$ & $0.531^{*}$ & $41.74 \pm 29.08$ & $104.48 \pm 149.07$ & $0.150^{*}$ \\
\hline S3 & $26.52 \pm 29.87$ & $20.91 \pm 13.24$ & $0.461^{*}$ & $23.78 \pm 18.35$ & $52.70 \pm 75.84$ & $0.066^{*}$ \\
\hline
\end{tabular}

*) Mann-Whitney test

$\mathrm{S} 1=$ first week from fever onset; $\mathrm{S} 2=$ second week from fever onset; $\mathrm{S} 3=$ third week from fever onset

Table 3. Comparison of mean alteration of transaminase leVels in RA and RL Groups

\begin{tabular}{|c|c|c|c|c|c|c|}
\hline \multirow{2}{*}{$\begin{array}{l}\text { Mean } \\
\text { transaminase } \\
\text { level alteration } \\
(\mathrm{U} / \mathrm{l}) \\
\end{array}$} & \multicolumn{3}{|c|}{ Without shock } & \multicolumn{3}{|c|}{ With shock } \\
\hline & $\begin{array}{l}\mathbf{R A} \\
(\text { mean } \pm S D)\end{array}$ & $\begin{array}{l}\mathbf{R L} \\
(\text { mean } \pm S D)\end{array}$ & $\mathbf{P}$ & $\begin{array}{l}\mathbf{R A} \\
(\text { mean } \pm S D)\end{array}$ & $\begin{array}{l}\mathbf{R L} \\
(\text { mean } \pm S D)\end{array}$ & $\mathbf{P}$ \\
\hline \multicolumn{7}{|l|}{ AST } \\
\hline $\mathrm{S} 1$ to $\mathrm{S} 2$ & $2.52 \pm 142.91$ & $17.43 \pm 60.48$ & $0.809^{*}$ & $2.34 \pm 62.92$ & $22.34 \pm 62.92$ & $0.328^{*}$ \\
\hline S2 to S3 & $69.26 \pm 119.16$ & $37.43 \pm 60.06$ & $0.097^{\star}$ & $42.30 \pm 44.98$ & $42.30 \pm 44.98$ & $0.684^{*}$ \\
\hline $\begin{array}{l}\text { S1 to S3 } \\
\text { ALT }\end{array}$ & $66.73 \pm 136.51$ & $20.00 \pm 21.85$ & $0.435^{\star}$ & $64.65 \pm 81.88$ & $64.65 \pm 81.88$ & $0.475^{\star}$ \\
\hline $\mathrm{S} 1$ to $\mathrm{S} 2$ & $11.73 \pm 95.33$ & $9.00 \pm 24.67$ & $0.605^{*}$ & $0.47 \pm 24.87$ & $0.47 \pm 24.87$ & $0.605^{\star}$ \\
\hline S2 to S3 & $33.60 \pm 91.33$ & $11.56 \pm 26.06$ & $0.750^{*}$ & $17.95 \pm 26.64$ & $17.95 \pm 26.64$ & $0.904^{*}$ \\
\hline S1 to S3 & $21.86 \pm 48.82$ & $2.56 \pm 14.49$ & $0.286^{*}$ & $17.47 \pm 37.65$ & $17.47 \pm 37.65$ & $0.302^{*}$ \\
\hline
\end{tabular}

*) Mann-Whitney test

$\mathrm{S} 1=$ first week from fever onset; $\mathrm{S} 2=$ =second week from fever onset; $\mathrm{S} 3=$ third week from fever onset 
on the first day of admission, on the 9th and 14th day since the onset of fever. However, patient incompliance made it difficult to obtain the blood samples on time. To cope with this obstacle, the blood samples were taken within the first, second and third weeks. Other studies also encountered difficulties in obtaining blood samples at a specific time. Mohan et al ${ }^{27}$ took blood samples on the first, second, third, and fourth weeks. Nguyen et all undertook a similar study with the first blood samples taken in the first week and second blood samples between the 8 th and 11th day since the first symptoms. Kuo et al ${ }^{24}$ took the first blood sample on the first week and the next samples between the 8th and 21st day. Lin et al ${ }^{22}$ also took the first blood sample in the first week and the second between the 10th and 14th day.

Most studies have focused on comparing RA and RL solutions by measuring lactate levels and observing acid-base disturbances in patients with shock, liver insufficiency, burns, diabetic ketoacidosis, and posthepatectomy patients. Presently, studies comparing transaminase levels after the use of RA and RL in DHF patients have not been found.

Initially, the AST levels were higher than ALT leves both in patients with and without shock (Table 2). These results are supported by the outcome of other studies and the speculation that myocytes or monocytes may contribute to the higher AST increase. ${ }^{22,25,29,30}$ This phenomenon differs from that in hepatitis virus-infected patients, in which the ALT level is higher than the AST level. AST is more specific and sensitive to detect hepatocellular impairment because its concentration is highest in the liver. In contrast, AST is produced by the liver, heart and skeletal muscles, kidney, pancreas, and monocytes. $^{32,33}$ In the early phase of DHF infection, a systemic impairment occurs which also affects myocytes and monocytes. According to Lin et al, liver cells infected by the dengue virus are another source of AST production. Moreover, the half-life of ALT (32-43 hours) is longer than that of AST (12,5-22 hours), which explains why AST declined more rapidly to normal levels (10 to 14 days after fever onset) than did ALT.22

In this study, marked disturbance of liver function indicating hepatocellular involvement was observed in all cases (Table 2). AST and ALT levels increased during the first week and reached its peak during the second week, then decreased to normal levels in the third week. This result is supported by that of Mohan, ${ }^{27}$ who found similar results.
The mean AST and ALT levels in the RA and RL groups without shock were highest on the second week and decreased in the third week, but this difference was not significant statistically. The mean AST and ALT levels in patients with shock was lower in the RA group than in the RL group, with again no significantly statistical difference. This suggests that RA does not burden the liver.

In conclusion, in DHF without shock, there is no significant difference between aminotransferase level changes of patients receiving RA dan RL solutions. In DHF with shock, aminotransferase levels of patients receiving RA tend to be lower than those receiving $R L$, but this difference is insignificant.

From our findings, we infer that either RA or $\mathrm{RL}$ can be used in the management of DHF patients without shock. Further study is needed in patients with shock, since the mean transaminase levels were lower in the RA group compared to RL group clinically, even though the differences were not significant statistically.

\section{References}

1. Harun SR. Telaah endotoksemia pada perjalanan penyakit demam berdarah dengue, perhatian khusus pada syok, produksi TNF-a, Interleukin-6, dan sebagai faktor prediktor demam berdarah dengue berat [dissertation]. Jakarta: Universitas Indonesia; 1996. p. 12-14.

2. Soedarmo SP. Demam berdarah dengue. Medika 1995;10:798-808.

3. Soedarmo SP. Masalah demam berdarah dengue di Indonesia. In: Harun SR, Satari HI, editors. Demam berdarah dengue, naskah lengkap pelatihan bagi pelatih dokter spesialis anak dan dokter spesialis penyakit dalam dalam tatalaksana kasus demam berdarah dengue. 1st ed. Jakarta: Balai Penerbit FKUI; 1999. p. 1-5.

4. Bethell DB, Gamble J, Pham PL, Nguyen MD, Tran TH, $\mathrm{Ha} \mathrm{TH}$, et al. Noninvasive measurement of microvascular leakage in patients with dengue haemorrhagic fever. Clin Infect Dis 2001; 32:243-53.

5. Wahid SF, Sanusi S, Zawawi MM, Ali RA. A comparison of the pattern of liver involvement in dengue hemorrhagic fever with classic dengue fever. Southeast Asian J Trop Med Public Health 2000;31:259-63.

6. Harun SR, Soegijanto S, Wuryadi S, Suroso T. Tatalaksana demam dengue/demam berdarah dengue 
pada anak. In: Harun SR, Satari HI, editors. Demam berdarah dengue, naskah lengkap pelatihan bagi pelatih dokter spesialis anak dan dokter spesialis penyakit dalam dalam tatalaksana kasus demam berdarah dengue. 1st ed. Jakarta: Balai Penerbit FKUI; 1999. p. 82 137.

7. Kurane I, Ennis FA. Cytokines in dengue virus infections: role of cytokines in the pathogenesis of dengue haemorrhagic fever. Semin Virology 1994;5:443-8.

8. Harun SR. Imunopatogenesis demam berdarah dengue. In: Akib AA, Tumbelaka AR, Matondang CS, editors. Naskah lengkap PKB IKA XLIV: Pendekatan imunologi berbagai penyakit alergi dan infeksi. Jakarta: Balai Penerbit FKUI; 2001. p. 41-57.

9. World Health Organization. Dengue hemorrhagic fever: diagnosis, treatment, prevention, and control. 2nd ed. Geneva: WHO; 1997. p. 1-33.

10. World Health Organization. Guidelines for treatment of dengue fever/dengue haemorrhagic fever in small hospitals. 1st ed. New Delhi: WHO Regional Office for South-East Asia; 1999. p. 16-8.

11. Latief A. Pemilihan cairan resusitasi pada anak: kontroversi antara koloid dan kristaloid. In: Chair I, Purwanto SH, Pudjiadi A, editors. Naskah lengkap PKB IKA XXX: Pendekatan farmakologik pada pediatri gawat darurat. Jakarta: Bagian Ilmu Kesehatan Anak Fakultas Kedokteran Universitas Indonesia; 1993. p. 37-50.

12. Sunatrio S. Resusitasi cairan. 1st ed. Jakarta: Media Aesculapius FKUI, 2000. p. 1-120.

13. Sunatrio S. Larutan Ringer asetat dalam praktek klinis. Presented at Simposium Alternatif Baru dalam Terapi Resusitasi Cairan; 1999 Aug 14; Jakarta, Indonesia.

14. Madiyono B, Moeslichan S, Sastroasmoro S, Budiman I, Purwanto SH. Perkiraan besar sampel. In: Sastroasmoro S, Ismael S, editors. Dasar-dasar metodologi penelitian klinis. 2nd edition. Jakarta: Sagung Seto; 2002. p. 259-86.

15. Suvatte V, Vajaradul C, Laohapand. Liver failure and hepatic encephalopathy in dengue hemorrhagic fever/ dengue shock syndrome: correlation study with acetaminophen usage. Southeast Asian J Trop Med Public Health 1990;21:694-5.

16. Innis BL. Acute liver failure is one important cause of fatal dengue infection. Southeast Asian J Trop Med Public Health 1990;21:695-6.

17. Soedarmo SP. Patofisiologi dan patogenesis. In: Sumarmo, editor. Demam berdarah dengue pada anak. 2nd ed. Jakarta: FKUI; 1988. p. 27-33.

18. Harun SR, Soegijanto S, Wuryadi S, Suroso T. Tatalaksana demam dengue/ demam berdarah dengue. 1st ed. Jakarta: Ditjen P2MPLP Departemen Kesehatan RI; 1999. p. 1-6.
19. Juffrie $M$, Haasnoot K, Thijs LG. Dengue virus infection and dengue hemorrhagic shock. Crit Care and Shock 2000;3:139-45.

20. Chameides L, Hazinski MR. Recognition of respiratoy failure and shock. In: Aehlert B, editor. Pediatric Advanced Life Support. St Louis: Mosby; 1997. p. 1- 10.

21. Lin YL, Liu CC, Lei HY, Yeh TM, Lin YS, Chen RM, et al. Infection of five human liver cell lines by dengue-2 virus. J Med Virol 2000; 60:425-31.

22. Krishnamurti C, Kalayanarooj S, Cutting MA, Peat RA, Rothwell SW, Reid TJ, et al. Mechanisms of hemorrhage in dengue without circulatory collapse. Am J Trop Med Hyg 2001;65:840-7.

23. Huerre MR, Lan NT, Marianneau P, Hue NB, Khun $\mathrm{H}$, Hung NT, et al. Liver histopathology and biological correlates in five cases of fatal dengue fever in Vietnamese children. Virchows Arch 2001;438:107-15.

24. Kuo CH, Tai DI, Chang-Chien CS, Lan CK, Chiou SS, Liaw YF. Liver biochemical tests and dengue fever. Am J Trop Med Hyg 1992;47:265-70.

25. Nguyen TL, Nguyen TH, Tieu NT. The impact of dengue haemorrhagic fever on liver function. Res Virol 1997;148:273-7.

26. Mohan B, Patwari AK, Anand VK. Hepatic dysfunction in childhood dengue infection. J Trop Pediatr 2000;46:40-3.

27. Johnston DE. Special considerations in interpreting liver function tests. Am Fam Physician 1999;59:2223-30.

28. Wang LY, Chang WY, Lu SN, Chen TP. Sequential changes of serum transaminase and abdominal sonography in patients with suspected dengue fever [abstract]. Gaoxiong Yi Xue Ke Xue Za Zhi 1990;6:483-9.

29. Nguyen TH, Lei HY, Nguyen TL, Lin YS, Huang KJ, Le BL, et al. Dengue hemorrhagic fever in infants: a study of clinical and cytokine profiles. J Infect Dis 2004;189:221-32.

30. Pancharoen C, Rungsarannont A, Thisyakorn U. Hepatic dysfunction in dengue patients with various severity [abstract]. J Med Assoc Thai 2002;85 (Suppl): 298-301.

31. Martin P, Friedman LS. Assessment of liver function and diagnostic studies. In: Friedman LS, Keeffe EB, editors. Handbook of liver disease. 1st ed. London: Churchill Livingstone; 1998. p. 1-4.

32. Maller ES. Laboratory assessment of liver function and injury in children. In: Suchy FJ, editor. Liver disease in children. 1st ed. Missouri: Mosby; 1994. p. 269-80.

33. Ganong WF. Keseimbangan energi, metabolisme dan nutrisi. In: Ganong WF, editor. Fisiologi kedokteran. 10th ed. Jakarta: ECG Penerbit Buku Kedokteran; 1988. p. 236-270. 